\title{
POVERTY AND WEALTH \\ FROM THE PERSPECTIVE OF SELECTED PSYCHOLOGICAL CONCEPTS OF VALUE
}

The purpose of the paper is to discuss the issues associated with the psychological aspect of possessions. The basic question of our consideration refers to the place which poverty and wealth occupy among human values. In particular, the analysis of this article includes recognition of Milton Rokeach and Shalom H. Schwartz.

Keywords:social psychology, human values, poverty, wealth.

doi:10.2478/sho-2014-0007

The attitude to material goods, possessions or money is a matter of interest of psychologists in the biological (anthropological, cultural, sociobiological), individual and interpersonal fields. The materialistic attachment to the objects is in fact conditioned by the personality of a man as well as it results from the socio - cultural context, which is the source of patterns of behaviors, norms and values that a person can use ${ }^{1}$.

The concept of value proposed by Milton Rokeach belongs to the domain of the concept of personality. What differentiates this concept from others and was a novelty in this regard is the inclusion of a cognitive perspective: Rokeach defined personality as a system of beliefs. This system consists of 10 subsystems, from the most central to the most peripheral of which the most central system is a set of beliefs about the self (values are

${ }^{1}$ See M. Górnik-Durose, Z. Zaleski, Wtasność i posiadanie, [in:] T. Tyszka (Ed.), Psychologia ekonomiczna, Gdańsk 2004, p. 139 - 149. 
close to the structure of " $\mathrm{I}$ " but are not included in its composition"). These systems are as follows ${ }^{3}$ :

- cognitions about self,

- terminal value system: personal and social,

- instrumental value system: moral and competence,

- attitude systems (two attitudes connected with each other),

- attitude,

- cognitions about own behavior,

- cognitions about other's significant attitudes,

- cognitions about other's significant values or needs,

- cognitions about other's significant behavior,

- cognitions about behavior of nonsocial objects.

Systems of values are in a crucial place of the system of beliefs and have an important regulatory function.

Individual beliefs that can best be described as a claim with which the person may agree to form a belief system. Single beliefs may take the form of: descriptive beliefs (existential), evaluative beliefs and prescriptive or proscriptive beliefs. The first term refers to what is a truth and what a falsehood is; the second, to what is good and what is bad; and the third, to what is desirable and undesirable. Prescriptive or proscriptive beliefs are performing the central position in the system of beliefs. The values are an expression of belief in the third type; they are telling you that a certain way of conduct, or the ultimate state of existence is preferred by the entity or socially acceptable in relation to the other ${ }^{4}$. According to Rokeach, values have a significant advantage over the features, because features in the very nature of things are immutable, are a permanent predisposition, and changes can not appear through the entire life. What is more, preferences although they are relatively constant, may be overvalued ${ }^{5}$.

Rokeach proposed a catalog of 36 terminal values (among them are the personal and social) and instrumental (among them are distinguished moral values and competence). In his opinion, people are not so different in preferred values as they are in their hierarchy. A catalogue of values proposed by Rokeach is as follows:

- a comfortable life (a prosperous life),

- an exciting life (a stimulating, active life),

${ }^{2}$ M. Rokeach, The nature of human values, New York: The Free Press 1973, p. 215 - 224.

${ }^{3}$ M. Rokeach, The nature of human values, New York: The Free Press 1973, p. 7 -8, 220 $-221$.

${ }^{4}$ M. Rokeach, The nature of human values, New York: The Free Press 1973, p. 5 -7.

${ }^{5}$ M. Rokeach, The nature of human values, New York: The Free Press 1973, p. 21. 
- a sense of accomplishment (lasting contribution),

- a world at peace (free of war and conflict),

- a world of beauty (beauty of nature and the arts),

- equality (brotherhood, equal opportunity for all),

- family security (taking care of loved ones),

- freedom (independence, free choice),

- happiness (contentedness),

- inner harmony (freedom, from inner conflict),

- mature love (sexual and spiritual intimacy),

- national security (protection from attack),

- pleasure (an enjoyable, leisurely life),

- salvation (saved, eternal life),

- self-respect (self-esteem),

- social recognition (respect, admiration),

- true friendship (close companionship),

- wisdom (a mature understanding of life)

and include the terminal values. Whereas instrumental values are the following:

- ambitious(hard-working, aspiring),

- broadminded (open-minded),

- capable (competent, effective),

- cheerful(lighthearted, joyful),

- clean (neat, tidy),

- courageous (standing up for your beliefs),

- forgiving (willing to pardon others),

- helpful (working for the welfare of others),

- honest (sincere, truthful),

- imaginative (daring, creative),

- independent (self-reliant, self-sufficient),

- intellectual (intelligent, reflective),

- logical (consistent, rational),

- loving (affectionate, tender),

- obedient (dutiful, respectful),

- polite (courteous, well-mannered),

- responsible (dependable, reliable),

- self-controlled (restrained, self-disciplined) 6 .

A research regarding the importance of value in the development of a person was conducted by Jan Cieciuch. It has shown that, with regard to

\footnotetext{
${ }^{6}$ M. Rokeach, The nature of human values, New York: The Free Press 1973, p. 28.
} 
the value of reinforcing oneself, the regularities are curved ${ }^{7}$ Preference of the value of power declines until about 10 years old, and then it is steadily growing.

The examination of the personal values on the materialistic knowledge were conducted Anna Zawadzka. In the examinations, the following were applied: Scale of the Materialistic Orientation, inspired by the concept of M. L. Richins and S. Dawson, and a set of values of M. Rokeach (adapted by P. Brzozowski). Examinations showed that personal values were connected with a materialistic orientation, and they are explaining it in $29 \%$ of cases. The materialistic orientation is correlating positively with "life of affluence", and negatively with "wisdom", with "internal balance" and

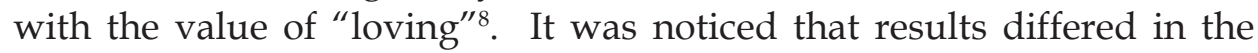
group of examined women and men, and the second factor, apart from the sex, that differs is the age of those people examined.

The "comfortable life" value is reflected in the final Rokeach value system. On the basis of the theory of Rokeach, C. S. Johnstown proposes in his study the existence of two general dimensions, hidden both in the final values and the instrumental ones, measured with the use test of Rokeach: individualism - collectivism - achievement and affiliation?. Both individualism and collectivism are expressions of the fundamental trends of man to the world, which are also expressed in the sphere of evaluation $^{10}$.

The study of attitude to tangible goods, depending on the collectivism / individualism was carried out in Poland and Great Britain by Malgorzata Gornik - Durose, and showed that individualistic orientation at both the individual and the cultural level is associated with materialism $^{11}$. In contrast, people and culture-oriented collectivist attach less importance to possessions, but nevertheless they appreciate them because of their social meaning and reference. Materialism is understood as the va-

${ }^{7}$ J. Cieciuch, Kształtowanie się systemu wartości od dzieciństwa do wczesnej dorostości, Warszawa 2013, p. 280.

${ }^{8}$ A. M. Zawadzka, Wartości osobiste ttumaczące orientację materialistyczna jednostki. Roczniki Psychologiczne 2006, tom IX, nr 2, pp. 61 -80.

${ }^{9}$ C. S. Johnston, The Rokeach Value Survey: Underlying structure and multidimensional scaling. The Journal of Psychology, 129, 5, 1995, pp. 583-597.

10 See S. Oishi, U. Schimmack, E. Diener, E. M. Suh, The measurement of values and individualism collectivism. Personality and Social Psychology Bulletin, 24, 1998, s. 1177-1189.

${ }_{11}$ M. Górnik - Durose, Psychologiczne aspekty posiadania między instrumentalnościa a społeczna użytecznościa dóbr materialnych, Katowice 2002, pp. 223 - 228. 
lidity of which man gives to owned property, locating them in the center of life's activity ${ }^{12}$.

Just as M. Rokeach, Shalom H. Schwartz defines values as beliefs. As the starting point of his research, he adopted Rokeach's theory, assuming it can be modified at the same time. In such understanding, values are the concepts and beliefs that relate to the desired end-states or behaviors, go beyond specific situations and guide the selection or evaluation of behaviors and events. They are also ordered according to their relative importance. Their number is limited, and they are present in different cultures, although the relation to them may be different. The values have a significant relationship with emotions, such as a joy of resources or sorrow because of the loss. Here is a clear superiority of values to attitudes, because the specific conduct or evaluation may result from the influence of more than one attitude.

The values understood in this way, differ from attitudes in several aspects. First of all, in their generality and abstractness and their hierarchical arrangement of importance, they are also an expression of an intentional response to the demands of human existence, and express themselves in the form of conscious objectives formulated by the individual. These include both biological and social needs, and the needs of coordination of social interaction (values are the tool of this coordination) and the needs of the groups associated with the survival and prosperity of the interests expressed by the target; objectives can express individual or group needs ${ }^{13}$. Schwartz, when referring to values as cognitive representations as one of the approaches, assumes that they are also the interests of the individual and the general and refers here to the dimension of individualism-collectivism, common in the literature ${ }^{14}$. In his later works, Schwartz ignores the aspect of attitudes and applies values only to convictions, cognitive structures ${ }^{15}$. Values are determinants of human motivation because they relate to states, desirable objectives, but not so much to specific situations. They

\footnotetext{
12 R. W. Belk, Materialism. Trait aspects of living in the material world. Journal of Consumer Research, 12, 1985, pp. 265 - 280.

${ }^{13}$ S. H. Schwartz, Universals in the content and structure of values: Theoretical advances and empirical tests in 20 countries, Advances in Experimental Social Psychology, 25, 1992, s. 1-65, S. H., Schwartz, Basic human values: theory measurement and applications. Revue francaise de sociologie, 47, 4, 2006, pp. 929-968.

14 S. H. Schwartz, W. Bilsky, Toward a psychological structure of human values. Journal of Personality and Social Psychology 1887, 53(3), pp. 550-562.

15 S. H. Schwartz, Basic human values: theory measurement and applications. Revue francaise de sociologie, 47, 4, 2006, pp. 929-968.
} 
are in fact over them, for example: obedience and honesty. The consequence of this is that they direct the events, define standards and criteria ${ }^{16}$. It does not always so occur in a manner accessible to human consciousness, and it becomes conscious in a conflict between the values when the unit must make specific choices. Values are hierarchically ordered; they characterize priorities of a unit, while the specific behavior may be the expression of multiple values. So to explain behavior by the value, you should take into account their whole system ${ }^{17}$. Taking action consistent with a given value carries implications for other values consistent or inconsistent with them. The actions resulting from the values have practical, psychological and social consequences. Practically, they rely on the fact that choosing an alternative action that promotes one value makes it possible to infringe upon competing values, and this can arouse a feeling of dissonance. Another kind are social consequences resulting from noticing practical and logical inconsistencies between actions and other values that a man confesses ${ }^{18}$. Of course, people can and do operate competing values, but not in the same case and if they do, they do it in different activities. After analyzing the research, Schwartz has identified 10 motivational types of values, comprising 54 individual values:

- power: social status and prestige, control or dominance over

- people and resources,

- achievement: personal success through demonstrating competence

- according to social standards,

- hedonism: pleasure and sensuous gratification for oneself,

- stimulation: excitement, novelty, and challenge in life,

- self-direction: independent thought and action-choosing, creating, exploring,

- universalism: understanding, appreciation, tolerance, and protection for the welfare of all people and for nature,

- benevolence: preservation and enhancement of the welfare of people with whom one is in frequent personal contact,

- tradition: respect, commitment, and acceptance of the customs and ideas that traditional culture or religion provide the self,

- conformity: restraint of actions, inclinations, and impulses likely to upset or harm others and violate social expectations or norms,

16 ibidem
17 ibidem
18 ibidem 
- security: safety, harmony, and stability of society, of relationships, and of self.

The key thesis of the theory of Schwartz is the claim regarding the structure of values that, according to the statement of the author, they are arranged in a circular continuum, the consequence of which is a possible varied division of the circle. It is possible to divide the circle into ten values or four values of a higher order. Division takes into account that the higher-order is determined by the ends of the two dimensions of a circle: crossing each other, including universalism and benevolence versus strengthening each other, including power, achievement, hedonism, and openness to change involving stimulation, directing them versus conservatism, including tradition, adaptation and security ${ }^{19}$.

Schwartz defines two rules ordering the values in the wheel: rules of compliance and conflict. It is possible to co-realize adjacent values in the circular model since they are cognitive representation of similar objectives, and sometimes it is impossible to co-realize values lying on opposite sides of the wheel, as cognitive representations are conflicting objectives. The hierarchy of adopted values is the expression of individual differences between people.

As a result of extensive research in 2012, Schwartz and his co-workers modified the concept of value and expanded the list to 19 items ${ }^{20}$. Extracting additional value was due to a more precise division of wheels:

- self-direction - thought: freedom to cultivate one's own ideas and abilities,

- self-direction - action: freedom to determine one's own actions,

- stimulation: excitement, novelty, and change,

- hedonism: pleasure and sensuous gratification,

- achievement: success according to social standards,

- power-dominance: power through exercising control over people,

- power-resources: power through control of material and social resources,

- face security and power through maintaining one's public image and avoiding, humiliation,

19 S. H. Schwartz, Basic human values: theory measurement and applications. Revue francaise de sociologie, 47, 4, 2006, pp. 929-968.

20 S. H. Schwartz, J. Cieciuch, M. Vecchione, E. Davidov, R. Fischer, C. Beierlein, A. Ramos, M. Verkasalo, J.-E. Lönnqvist, K. Demirutku, O. Dirilen-Gumus, M. Konty, Refining the theory of basic individual values. Journal of Personality and Social Psychology, 103(4), 2012, pp. 663-688. 
- security-personal: safety in one's immediate environment,

- security-societal: safety and stability in the wider society,

- tradition: maintaining and preserving cultural, family, or religious traditions,

- conformity-rules: compliance with rules, laws, and formal obligations,

- conformity-interpersonal: avoidance of upsetting or harming other people,

- humility: recognizing one's insignificance in the larger scheme of things,

- benevolence-dependability: being a reliable and trustworthy member of the in group,

- benevolence-caring: devotion to the welfare of in group members,

- universalism-concern: commitment to equality, justice, and protection for all people,

- universalism-nature: preservation of the natural environment,

- universalism-tolerance: acceptance and understanding of those who are different from oneself ${ }^{21}$.

Research conducted by S.H. Schwartz and T. Ruble in 70 countries over the differences in the perception of the value showed that examined men and women differ in the importance they attach to fundamental values ${ }^{22}$ . These differences are not significant; they show that men attach greater importance than women to power, stimulation, hedonism, achievements and leading themselves, while women attribute greater importance to benevolence and universalism.

Poverty and wealth do not appear directly in the Schwartz's catalog. Both states, however, are sets of intentional human actions. In a circular continuum it is a component for power (10-element), in which in later works authorities have replaced people and control has replaced (power) resources, such as material and social ones. It is the element of the circular continuum, which relates to reinforcing oneself. Authority over resources is adjacent to prestige and further to safety, and power over people to achievements and further to hedonism, while power over people is placed at the other end of the continuum in opposition to universalism. Values

${ }^{21}$ Ibidem

22 S. H. Schwartz,T. Rubel, Sex Differences in Value Priorities: Cross-Cultural and Multimethod Studies, Journal of Personality and Social Psychology, 2005, Vol. 89, No. 6, pp. 1010-1028. 
for power over people have the goal of promoting their own interests by checking what is going on and thus minimizing or avoiding risks. Power over resources is a control of events using their resources. Also, the power is linked to prestige, which applies to both power and security which allows both the protection of resources and control of other people ${ }^{23}$.

Wealth may therefore be a result of the incentive system of values in which priority is a power. The essence of collecting material goods takes on special meaning in the social perspective. In terms of social constructionism, Dittmar formulates assumptions about the importance of possessions ${ }^{24}$. They are a symbol of personal identity, social interactions other people run with regard to material goods units, which contributes to auto defining from the perspective of symbolic importance of possessions. Ownership of a unit also contributes to assign its proper place in the socio - material hierarchy. The importance of each of the goods results from social arrangements. Thus, they themselves become the message.

Although poverty and wealth are widely and commonly associated with wealth or lack of financial resources and deficits, they still take specific scientific shape by becoming an emanation of value in the psychological approaches, they take specific scientific shape. Theories of value and others associated with them do not fully reflect the concept of explaining the psychological aspects of ownership. There are a number of positions arising even from the individual perspective explaining the importance of possessions for the individual.

${ }^{23}$ H. Schwartz, J. Cieciuch, M. Vecchione, E. Davidov, R. Fischer, C. Beierlein, A. Ramos, M. Verkasalo, J.-E. Lönnqvist, K. Demirutku, O. Dirilen-Gumus, M. Konty, Refining the theory of basic individual values. Journal of Personality and Social Psychology, 103(4), 2012, pp. 663-688.

${ }^{24} \mathrm{H}$. Dittmar, The social psychology of material possessions: to have is to be, Harvester Wheatsheaf, Hemel Hempstead and St Martin's Press, New York, 1992 za: M. GórnikDurose, Z. Zaleski, Wtasność i posiadanie, [in:] T. Tyszka (ed.), Psychologia ekonomiczna, Gdańsk 2004, pp. 147-149. 